\title{
Beliefs and attitudes in patients with chronic low back pain
}

\author{
Crenças e atitudes frente à dor em pacientes com lombalgia crônica
}

Fernanda Martins Barbosa1 , Érica Brandão de Moraes Vieira², João Batista Santos Garcia ${ }^{3}$

DOI 10.5935/2595-0118.20180023

\section{ABSTRACT}

BACKGROUND AND OBJECTIVES: Dysfunctional attitudes and beliefs in patients with low back pain may interfere with pain, disability, and mood. The objective of this study was to evaluate the behavior of beliefs and attitudes in chronic low back pain and to correlate them with the intensity of pain, disability, anxiety, and depression.

METHODS: We evaluated 82 patients with chronic low back pain according to the Numerical Scale of Pain, Survey of Pain Attitudes, Hospital Scale of Anxiety and Depression, and Oswestry Disability Index.

RESULTS: More than half of the patients were female $(51.22 \%)$ with a mean age above 40 years. The pain was mild to moderate at $53.65 \%$. Severe disability was observed in $64.63 \%$, anxiety in $63.41 \%$ and depression in $41.46 \%$. The solicitude and disability beliefs showed significant associations in all groups. For physical damage, there was an association with disability and anxiety. Medical cure correlated between the anxiety variable.

CONCLUSION: Patients presented dysfunctional beliefs associated with the intensity of pain, anxiety, depression and mainly disability, with a probable influence on the treatment. This relationship shows how important it is to carry out new studies that evaluate therapeutic approaches, such as targeted interventions and educational programs, aimed at the patient's beliefs with low back pain to determine their impact on pain control and treatment.

Keywords: Anxiety, Back pain, Beliefs, Depression, Disability.

\section{RESUMO}

JUSTIFICATIVA E OBJETIVOS: Atitudes e crenças disfuncionais em pacientes com lombalgia podem interferir nos quadros de dor, incapacidade e humor. O objetivo deste estudo foi avaliar o comportamento das crenças e atitudes na lombalgia crônica e correlacioná-las com a intensidade da dor, incapacidade, ansiedade e depressão.

MÉTODOS: Foram avaliados 82 pacientes com lombalgia crônica segundo a Escala Numérica da Dor, Inventário de Atitudes Frente à Dor, Escala Hospitalar de Ansiedade e Depressão, e Índice Funcional de Oswestry.

RESULTADOS: Mais da metade dos pacientes foi do sexo feminino $(51,22 \%)$ com idade média acima de 40 anos. A dor era leve à moderada em 53,65\%. Observou-se incapacidade grave em $64,63 \%$, ansiedade em $63,41 \%$ e depressão em $41,46 \%$. As crenças solicitude e incapacidade apresentaram associaçôes significativas com todos os grupos. Para dano físico, houve associação com incapacidade e ansiedade. A cura médica se correlacionou com a variável ansiedade.

CONCLUSÁO: Os pacientes apresentaram crenças disfuncionais associadas à intensidade da dor, ansiedade, depressão e principalmente incapacidade, com provável influência no tratamento. Ao demonstrar essa relaçáo, se evidencia importância da realização de novos estudos que avaliem abordagens terapêuticas, como intervençóes dirigidas e programas educacionais, voltadas para as crenças do paciente com lombalgia para determinar seu impacto no controle e tratamento da dor.

Descritores: Ansiedade, Crenças, Depressão, Dor lombar, Incapacidade.

\section{INTRODUCTION}

Low back pain or chronic lumbago is an unspecific term that refers to the continuous pain in the lumbosacral region. It appears as a frequent type of chronic pain, reaching about $20 \%$ of the world's population with great consequences to the functional capacity of the affected individuals ${ }^{1-3}$. Due to its high prevalence rate and resulting disability, chronic low back pain is a public health problem that generates high costs for the healthcare and social security services ${ }^{4,5}$.

Pain is a subjective and personal experience, and its presence in the chronic form brings not only biological changes but emotional, cognitive and also behavioral changes ${ }^{6}$. Evidence showed that patients with chronic pain that had depression, anxiety and anguish have reported higher intensity of pain and disability ${ }^{7,8}$. Such relations are established in the Cognitive-Behavioral approach in the treatment of the pain, that points the 
values, attitudes, beliefs, expectations and the patient's judgment about pain as determinant factors in the painful experience and pain control ${ }^{9,10}$.

Beliefs are culturally learned certainties; they are each individual's notion concerning its own reality, of the others and of the space, which interferes with the behavior ${ }^{9-11}$. Attitudes are organized in affective arrangements, relatively stable, that reflect the trend to respond positively or negatively to something or some event. Both are formed from personal experiences-11. Beliefs and attitudes influence the acceptance, the results and the satisfaction with treatment, also impacting the capacity of individuals to build an active and satisfactory life, despite the pain $^{6,9,10}$.

Several studies also emphasized that even in eminently organic pictures, other psychological aspects have been relevant in pain complaint ${ }^{12,13}$. Therefore, the chronic pain syndromes can also favor the onset of depression and anxiety, with repercussions in the capacity of the patients, as well as some beliefs. Somehow, the dysfunctional beliefs can also contribute to the onset of these disorders, and the establishment of this relationship is a positive factor in the treatment, and since beliefs are acquired, they can be modified ${ }^{2,9}$.

Recognizing the influence of the beliefs and attitudes in the painful experience and the functionality, this study aimed to evaluate the beliefs and attitudes of patients with chronic low back pain and to establish its correlation with the intensity of pain intensity, level of disability, anxiety, and depression.

\section{METHODS}

A cross-sectional and quantitative inquiry conducted in the chronic pain clinic of the Presidente Dutra University Hospital of the Federal University of the Maranhano (UFMA). The study population was composed of patients registered and cared for at the chronic pain clinic of the UFMA. The population with low back pain of the clinic was of 164 patients. It was decided to get a sample of $50 \%$ of this population, with a test power of $90 \%$. The calculation used was the minimum sample size with $90 \%$ of confidence level and sample error of $6.5 \%$ :

$$
\mathrm{n}=\frac{1.6442 \times 0.13 \times(1-0.13)}{0.0652}=72.35 \cong 73
$$

The resulting sample was of 82 patients, by convenience, when patients were at the pain clinic for treatment. Initially, all participants were cared for in a conventional visit, already routinely used, when the inclusion and exclusion criteria were evaluated for the application of the instruments used in the research. The inclusion criteria were to be above 18 years of age, to have low back pain for more than six months and no indication of surgical treatment and/or anesthetic blockade. People with psychiatric disorders and with understanding and verbalization impairment were excluded. Patients were briefed, and those who agreed to participate in the study signed the Free an Informed Consent Form (FICT).
The subjects completed three instruments already validated for the Brazilian-Portuguese language, the initial patient's record used by the institution, which includes socioeconomic data and issues related to the pain picture, as pain intensity according to the numeric pain rating scale (NPRS) ${ }^{9}$.

For the beliefs facing pain, the Brief Pain Inventory (BPI-brief) was used, validated for the Portuguese language in 2006. The purpose of this instrument is to evaluate the attitudes and beliefs facing pain in patients with non-oncologic chronic pain ${ }^{10}$. It has 30 items corresponding to seven domains: solicitude, emotion, medical cure, control, disability, physical damage, and medication. It is a One is about a self-applied instrument in which the participants provide answers in a Likert-type scale of five scores that varies from zero to 4 (zero=totally false, $1=$ false, $2=$ neither true nor false, $3=$ almost true, $4=$ totally true $)^{10,14}$.

The "solicitude" domain relates to how much the patient believes that his/her family and other people should be more solicitous during the pain episodes, and is represented by items 3, 7, 9, 14 and 18 of the BPI. "Emotion" relates to the belief of the emotional effects, good or bad, in the painful experience, and is represented by items 6,10,15 and 25. "Medical Cure" relates to how much the patient believes in medicine to cure his/her pain and is represented in the questions 4, 8, 21, 24 and 29. "Control" relates to how much the patient believes that he/she has control over his/her pain, and is represented in the questions 1, 12, 17, 20 and 22. "Disability" relates to how much the patient believes that the pain has disabled him/her, and is represented in the questions 23, 26 and 30 of the inventory. "Physical Damage" relates to how much, in the patient's point of view, the pain hurts him/herself, and because of it, exercises should be avoided. It is represented by items $11,16,19$, 27 and 28. "Medication" relates to how much the patient believes that drugs are the best treatment for chronic pain and it is represented by questions 2,5 and 13 of the instrument ${ }^{10,11,14}$. The score was obtained by adding the points of the answer of each item, divided by the number of the answered items. Some inverted items $(4,8,11,23,24,26,27,28,29)$ must have their scores reverted before summing, and the reversion of the score done by subtracting the score chosen by the patient from 4 . In the inventory, there are no right or wrong answers. Therefore, the score obtained is compared with the desirable orientations, characterized by the inventory author as the most adaptative. The desirable orientation (DO) is zero for solicitude, cure, disability, physical damage, and medication. For emotion and control, it is equal to $4^{10,11,14}$.

The Hospital Anxiety and Depression Scale (HADS) was the instrument used to evaluate anxiety and depression in the study. It was initially designed to evaluate hospitalized non-psychiatric clinical patients. In 2006, HADS was validated for patients with chronic pain ${ }^{15}$. This instrument has 14 items, of which seven evaluate anxiety and seven evaluate depression. Each item can have a score from zero to 3, giving a maximum score of 21 for each scale. The cut-off point for anxiety is 8 , and 9 for depression ${ }^{15}$.

The Oswestry Disability Index (ODI) published in 1980 is recognized as one of the main instruments to measure the disability 
in patients with spine alterations, where it is possible to determine the impact of pain on daily activities ${ }^{16,17}$. The version 2.0 of the ODI (Annex IV) was translated and validated for the Portuguese language, and it was adopted in this study ${ }^{16}$. It has 10 sections, each containing 6 statements related to limitations in daily activities as well as limitations in the sexual life. Each statement has a score from zero (absence of dysfunction) to 5 (great dysfunction). The total score obtained was divided by the number of answered questions multiplied by 5 (the maximum score by section). The result of this division was multiplied by 100 , and the final values are presented in percentage. Thus, the BPI classifies patients in minimum disability (zero-20\%); moderate (21-40\%); severe (4-60\%); very severe (61-80\%); and bedridden individual or exacerbation of symptoms $(81-100 \%)^{16,17}$.

This study was approved by the Ethics Committee of the institution under number 232 of 2010.

\section{Statistical analysis}

The questionnaires were revised to check its completion, legibility of the information and encoding the answers in a database in the Microsoft Excel. The data obtained were presented in absolute and relative values. The statistical analysis was made by the Stata 14.0. software. First, the descriptive analysis was made to classify the groups according to the measuring instruments used. Then, Student's t-test was used to compare the averages of the variables about the beliefs of the brief pain inventory. $\mathrm{p} \leq 0.05$ was considered significant.

\section{RESULTS}

The sample of the study was of 82 participants, of which $51.22 \%$ were female and $48.78 \%$ male, as shown in table 1 that exhibits the epidemiological aspects and pain characteristics in the study. The most prevalent age range was the middle-aged adult $(67.07 \%)$, with an age average of $43.23 \pm 10.70$ years, minimum of 19 and maximum of 77 years. More than half of the patients had 6 to 11 years of formal schooling $(56.09 \%)$ and had denied doing regular physical exercise.

According to NPRS, $53.65 \%$ of the patients had pain from mild to moderate intensity (NPRS=1-6). Pain onset for over 48 months was predominant $(63.41 \%)$ with an average time of the onset of $100.68 \pm 83.82$ months, with a minimum duration of 7 and maximum of 370 months. The pain was described as a factor that disturbs sleeping in $76.82 \%$ of the interviewed subjects, and the totality $(93.90 \%)$ said that the pain prevents them from carrying their activities satisfactorily. Among the non-retired patients $(n=70), 77.14 \%$ were on leave of absence by the time of the research due to chronic low back pain.

The characteristics of the beliefs and attitudes facing pain in the population of the study, besides the desirable orientation for each belief according to BPI, are shown in table 2. It is observed that the belief of physical damage with an average of $1.71 \pm 0.89$ is the one that is closest to the desirable orientation ( $\mathrm{DO}=$ zero) in the study population. On the other hand, the beliefs disability and medication, with averages of $3.10 \pm 0.94$ and $2.86 \pm 0.99$ respectively, were the farthest from the desirable orientation (zero).
Table 1. Epidemiological aspects and characteristics of pain in patients with chronic low back pain cared for in a clinic specialized in chronic pain in São Luís, MA

\begin{tabular}{|c|c|}
\hline Variables & $\begin{array}{l}\mathrm{n}(\%) \\
\mathrm{n}=82\end{array}$ \\
\hline \multicolumn{2}{|l|}{ Gender } \\
\hline Female & $42(51.22)$ \\
\hline Male & $40(48.78)$ \\
\hline \multicolumn{2}{|l|}{ Age (years) } \\
\hline Young adult (18-39) & $14(17.07)$ \\
\hline Middle-aged adult (40 - 59) & $55(67.07)$ \\
\hline Elderly $(\geq 60)$ & $13(15.86)$ \\
\hline Average (SD); median (min-max) & 43.23 (10.70); 49 (19-77) \\
\hline \multicolumn{2}{|l|}{ Schooling (years) } \\
\hline$<6$ & $28(34.14)$ \\
\hline 6 to 11 & $46(56.09)$ \\
\hline$>11$ & $8(9.77)$ \\
\hline \multicolumn{2}{|l|}{ Physical activity } \\
\hline Yes & $37(45.12)$ \\
\hline No & $45(54.88)$ \\
\hline \multicolumn{2}{|l|}{ Pain } \\
\hline Mild/moderate & $44(53.65)$ \\
\hline Severe & $38(46.35)$ \\
\hline \multicolumn{2}{|l|}{ Time of pain (months) } \\
\hline 6 to 18 & $6(7.32)$ \\
\hline 19 to 48 & $24(29.27)$ \\
\hline 49 to 370 & $52(63.41)$ \\
\hline Average (SD); median (min-max) & 100.68 (83.82); 72 (7-370) \\
\hline \multicolumn{2}{|l|}{ Pain disturbs sleeping } \\
\hline Yes & $63(76.82)$ \\
\hline No & $19(23.18)$ \\
\hline \multicolumn{2}{|c|}{ Pain prevents from working satisfactorily } \\
\hline Yes & 77 (93.90) \\
\hline No & $5(6.10)$ \\
\hline \multicolumn{2}{|l|}{ Leave of absence* } \\
\hline Yes & $54(77.14)$ \\
\hline No & 16 (22.86) \\
\hline
\end{tabular}

Table 2. Profile of the beliefs and attitudes facing pain, according to Brief Pain Inventory, in patients with chronic low back pain cared in a clinic specialized in chronic pain in São Luís, MA

\begin{tabular}{lcccc}
\hline Beliefs & $\begin{array}{c}\text { Desirable } \\
\text { orientation }\end{array}$ & Median & Average & $\begin{array}{c}\text { Standard } \\
\text { deviation }\end{array}$ \\
\hline Solicitude & 0 & 2.50 & 2.46 & 1.06 \\
Emotion & 4 & 2.75 & 2.54 & 1.09 \\
Cure & 0 & 3.00 & 2.81 & 0.84 \\
Control & 4 & 2.60 & 2.47 & 0.97 \\
Disability & 0 & 3.00 & 2.86 & 0.99 \\
Physical damage & 0 & 1.60 & 1.71 & 0.89 \\
Medication & 0 & 3.33 & 3.10 & 0.94 \\
\hline
\end{tabular}


The frequency of anxious patients in the study was of 63.41 and $41.46 \%$ of depressive, according to HADS. Regarding disability according to the ODI, $35.37 \%$ of the patients were classified as minimum to moderate disability, and $64.63 \%$ were classified as severe disability or bedridden. The profile of the study population, regarding the intensity of pain, disability, anxiety, and depression, and its correlation with each dependent variable represented by the beliefs of the BPI are shown in table 3 .
As it is observed in table 3, the belief of "solicitude" was significantly correlated with all the independent variables: intensity of pain $(\mathrm{p}=0.002)$, disability $(\mathrm{p}=0.0360)$, anxiety $(\mathrm{p}=0.005)$, depression $(\mathrm{p}=0.016)$. The averages for solicitude were farther from the desirable orientation (DO=zero) in the patients with intense pain $(2.92 \pm 0.92)$, severe disability to bedridden $(2.64 \pm 0.96)$, anxiety $(2.71 \pm 0.89)$ and depression $(2.80 \pm 0.81)$. Likewise, the belief "disability" also showed significant correlations with the

Table 3. Correlation of beliefs and attitudes facing severe pain intensity, disability, anxiety, and depression in patients with chronic low back pain

\begin{tabular}{|c|c|c|c|c|c|c|c|c|}
\hline \multirow[t]{2}{*}{ Variables } & \multicolumn{2}{|c|}{ Pain intensity } & \multicolumn{2}{|c|}{ Disability } & \multicolumn{2}{|c|}{ Anxiety } & \multicolumn{2}{|c|}{ Depression } \\
\hline & $\begin{array}{c}\text { Mild/ } \\
\text { Moderate }\end{array}$ & Intense & $\begin{array}{l}\text { Minimum/ } \\
\text { Moderate }\end{array}$ & $\begin{array}{c}\text { Severe/ } \\
\text { Bedridden }\end{array}$ & Anxious & Not anxious & Depressive & $\begin{array}{c}\text { Not } \\
\text { depressive }\end{array}$ \\
\hline $\mathrm{n}(\%)$ & 44 (53.65) & $38(46.35)$ & $29(35.37)$ & $53(64.63)$ & $52(63.41)$ & $30(36.59)$ & $34(41.46)$ & $48(58.54)$ \\
\hline \multicolumn{9}{|l|}{ Solicitude } \\
\hline Average & 2.07 & 2.92 & 2.13 & 2.64 & 2.71 & 2.04 & 2.80 & 2.23 \\
\hline$p$ value & $0.0002^{\star \star \star}$ & & $0.036^{*}$ & & $0.005^{\star \star}$ & & $0.016^{*}$ & \\
\hline \multicolumn{9}{|l|}{ Emotion } \\
\hline Average & 2.32 & 2.79 & 2.35 & 2.65 & 2.66 & 2.34 & 2.80 & 2.35 \\
\hline SD & 1.16 & 0.95 & 0.95 & 1.15 & 1.07 & 1.10 & 0.97 & 1.14 \\
\hline Average & 2.94 & 2.64 & 2.84 & 2.79 & 2.57 & 3.22 & 2.63 & 2.93 \\
\hline SD & 0.89 & 0.86 & 0.72 & 0.91 & 0.89 & 0.56 & 0.78 & 0.87 \\
\hline $\mathrm{Cl}$ & $2.70-3.20$ & $2.36-2.92$ & $2.56-3.11$ & $2.54-3.04$ & $2.32-2.82$ & $3.01-3.43$ & $2.36-2.90$ & $2.68-3.19$ \\
\hline$p$ value & 0.101 & & 0.818 & & $0.0005^{\star \star *}$ & & 0.111 & \\
\hline \multicolumn{9}{|l|}{ Control } \\
\hline Average & 2.62 & 2.29 & 2.61 & 2.40 & 2.45 & 2.50 & 2.42 & 2.51 \\
\hline SD & 0.86 & 1.08 & 0.96 & 0.98 & 0.93 & 1.07 & 0.94 & 1.00 \\
\hline $\mathrm{Cl}$ & $2.36-2.89$ & $1.93-2.65$ & $2.24-2.98$ & $2.12-2.67$ & $2.19-2.71$ & $2.09-2.92$ & $2.08-2.75$ & $2.21-2.80$ \\
\hline$p$ value & 0.132 & & 0.353 & & 0.830 & & 0.699 & \\
\hline Average & 1.64 & 1.78 & 1.37 & 1.89 & 1.91 & 1.36 & 1.86 & 1.60 \\
\hline SD & 0.83 & 0.95 & 0.83 & 0.87 & 0.91 & 0.75 & 0.88 & 0.88 \\
\hline $\mathrm{Cl}$ & $1.39-1.90$ & $1.47-2.10$ & $1.06-1.69$ & $1.65-2.13$ & $1.65-2.16$ & $1.08-1.64$ & $1.55-2.17$ & $1.34-1.86$ \\
\hline$p$ value & 0.469 & & $0.011^{*}$ & & $0.006^{\star \star}$ & & 0.194 & \\
\hline \multicolumn{9}{|l|}{ Medication } \\
\hline Average & 3.02 & 3.19 & 2.90 & 3.20 & 3.22 & 2.88 & 3.34 & 2.93 \\
\hline SD & 0.95 & 0.93 & 1.01 & 0.89 & 0.82 & 1.10 & 0.87 & 0.96 \\
\hline $\mathrm{Cl}$ & $2.73-3.31$ & $2.88-3.49$ & $2.52-3.29$ & $2.96-3.45$ & $2.99-3.45$ & $2.47-3.30$ & $3.03-3.64$ & $2.65-3.20$ \\
\hline$p$ value & 0.418 & & 0.171 & & 0.121 & & 0.050 & \\
\hline
\end{tabular}


same variables: intensity of pain ( $\mathrm{p}=0.014)$, disability $(\mathrm{p}=0.015)$, anxiety $(\mathrm{p}=0.011)$, depression $(\mathrm{p}=0.011)$; with an average farther from the desirable orientation (zero) in the cases of intense pain (3.14 \pm 0.58$)$, severe disability $(3.05 \pm 0.89)$, anxiety $(3.07 \pm 0.80)$ and depression (3.18 \pm 0.64$)$. In the analysis of the "physical damage" belief, the averages were also farther from the desirable orientation for all the variables. However, this belief was significantly related only to disability $(\mathrm{p}=0.011)$, and anxiety $(\mathrm{p}=0.0060)$, representing an average equal to $1.89 \pm 0.87$ in patients with severe disability and $1.91 \pm 0.91$ in patients classified as anxious. The "medical cure" belief significantly correlated only with the anxiety variable $(\mathrm{p}=0.005)$, in which the group of the non-anxious patients had the farthest average from the desirable orientation (3.22 \pm 0.56$)$. "Emotion", "control" and "medication" did not show significant correlation with none of the dependent variables in the study.

\section{DISCUSSION}

This study showed clinical characteristics of the chronic low back pain similar to those described in the literature $e^{2,18,19}$. Although many studies do not describe significant differences in chronic low back pain between genders, the prevalence found was higher in women ${ }^{5,20}$. This difference can be attributed to the accumulation of household chores and outside work, in addition to women's anatomical and functional characteristics ${ }^{18,20}$. The time of pain over 48 months in more than half of the sample warns of the chronicity of the disease, also reflecting the failures in the therapeutic method, either due to the lack of resources, access or even poor handling of the low back pain ${ }^{19,21}$.

The prevalent age range in the study, mainly middle-aged adults, was also compatible with the literature ${ }^{2,18,19}$. The greater presence of chronic low back pain in this age range, which represents the economically active population, creates problems not only for the physical health of the employed patient, but also social consequences as absenteeism, and social security expenses that constitute a public health problem ${ }^{5,22}$. The high proportion of patients on leave of absence found in the study, besides the high percentage that reported pain as an impeditive factor in the satisfactory development of the work and activities also favors this argument ${ }^{2,5,22}$. The alterations in sleep due to the chronic low back pain are very common results and show the impact of this painful syndrome on the quality of life and disability of the individual ${ }^{23}$. Similarly, the low level of physical activity due to pain $(54.88 \%)$ is another indicating factor of this disability ${ }^{2,6,24}$ that was ranked in $64.63 \%$ as severe to bedridden. The prevalence of severe disability in this study was higher than in other studies that used the $\mathrm{ODI}^{2,16,25}$, which confirms the disabling potential of the chronic low back pain, which can also be related to the profile of the sample, that is, patients cared for in a healthcare service suffering from this pain for a long time. The intensity of pain reported as intense by $46.35 \%$, is also presented as an important factor in determining the disability ${ }^{26}$.

Some studies, however, reported that psychosocial factors can have greater influence in the management of chronic pain and the impact on the patient's functioning than the pain itself ${ }^{2,8,15}$. This can be related to the frequency of entities as depression and anxiety, for example, found with percentages of 41.46 and $63.41 \%$, respectively, in this study. The relationship between depression and pain is widely addressed in the literature and pointed as the consequence and the cause of chronic pain worsening ${ }^{8,15,27}$. Depression can reduce the pain threshold and can be a result of its chronification and disability ${ }^{2,15,27}$. Regarding anxiety, articles showed that in these patients it is triggered by a fear reaction with the presence of concern, nervousness, and apprehension with regard to the disease, that favor higher levels of anxiety than in the general population ${ }^{13,15}$.

The beliefs and attitudes are also highlighted as part of the psychological and environmental factors that influence the persistence of the painful pictur ${ }^{2,6,7,10}$. Due to cultural and local influence, and place of beliefs creation, the frequencies vary in the literature, but generally, they are presented as a predictive factor of the individual's functioning ${ }^{10,14,28}$.

In the general analysis of the beliefs in the study, it was observed that the "physical damage" belief was the only one that presented an average close to the desirable orientation, that is, for these patients, pain is not necessarily related to physical damage. On the other hand, in this same analysis, the patients had non-adaptive beliefs about the other beliefs: solicitude, emotion, cure, control, disability, and medication. This indicates that patients expect people to be solicitous in the presence of pain, they do not accept that emotions influence the experience, they believe in the medical cure, they do not agree that they can have the personal control over pain, and they believe that the drug is the best treatment for chronic pain ${ }^{2,6,10,28}$.

Most of the studies that addressed beliefs and attitudes facing pain related these variables with disability and work activity, checking its effectiveness in predicting the patient's functioning $2,27,28$. In this study, the beliefs were also associated with the intensity of pain, anxiety, and depression, as well as disability, with a great number of statistically significant associations.

In patients with intense pain, the analysis showed the association with the dysfunctional belief of "solicitude", that is, the individual with intense pain expects a solicitous response to pain behavior. To be classified with severe disability, as anxious and as depressive was also associated with having a dysfunctional belief regarding solicitude. Believing that people must be more solicitous in the presence of pain is pointed as a factor that encourages and stimulates the patient to reduce the involvement in activities, reinforcing behaviors of avoidance with presence, mainly, of disability ${ }^{6,29}$. This same assertion can be applied to depressive patients who also tend to rest, presenting a passive attitude in relation to pain. Moreover, the inability to react to stressing events (as pain) increases the probability of future occurrences of depression and anxiety symptoms, and functional limitations $s^{2,27,29}$. Intense pain, severe disability, anxiety, and depression have also presented an association with the undesirable belief for "disability", that is, to believe that pain is disabling. This result was expected since several authors found a relationship between believing that pain is disabling and high levels of disability ${ }^{2,11,30,31}$. Likewise, psychosocial disorders as anxiety and depression play an important role in the perception of pain and make the patient believe that pain is the disabling cause, worsening his/her performance in functional activities $^{21,30}$. In the case of the patient with intense pain, the chronic pain 
is mistaken for acute pain, and the individual starts to restrict the movements and to reduce the activities to improve the situation, which, in reality, should not be applied for chronic pain ${ }^{19.21}$.

It was observed that all the groups obtained averages close to the desirable orientation for "physical damage", with a significant difference only in patients classified with severe disability and anxiety. In these groups, there was the association with the undesirable belief or pain related to physical damage, in which the patients do not recognize physical exercises as beneficial. The result for disability was compatible with the reports found in the literature, where the belief that pain indicates the presence of an injury and that exercises are a threat was described as a factor associated with behaviors of avoidance of activities and consequent increase in the chances of disability ${ }^{2.11 .31}$.

All the classified groups had an average far from the desirable orientation for the "medical cure" belief, with a significant relationship only with anxiety. There was an association between the undesirable orientation and non-anxious patients, which was not the expected result in the beginning. For the authors of the instrument used, believing in the medical cure would be considered a dysfunctional belief, because in many times there is no cure for chronic pain, and believing in it, patients would not collaborate with the therapeutical measures ${ }^{10,11,14}$. However, many studies also found divergent results for this idea, showing, instead, that when believing in the cure, the patient has a more positive attitude and tends to look for the pain control ${ }^{2,30}$. Thus, as found in this study, the non-anxious patients would tend to have more positive attitudes facing pain that the anxious ones, which helps the treatment.

\section{CONCLUSION}

It was observed in this study that patient with chronic low back pain often present dysfunctional beliefs in relation to pain and that such beliefs showed, in many cases, an association with the intensity of pain, anxiety, depression and mainly disability, with probable consequences in the therapeutic management of these patients.

\section{REFERENCES}

1. Wong W, Fielding R. Prevalence and characteristics of chronic pain in the general population of Hong Kong. J Pain. 2011;12(2):236-45.

2. Salvetti Mde G, Pimenta CA, Braga PE, Corrêa CF. [Disability related to chronic low back pain: prevalence and associated factors]. Rev Esc Enferm USP. 2012;46(Spec $\left.\mathrm{n}^{\circ}\right): 16-23$. Portuguese.

3. Rathmell JP. A 50-year-old man with chronic low back pain. JAMA. 2008;299(17):2066-77.

4. Lamb SE, Lall R, Hansen Z, Withers EJ, Griffiths FE, Szczepura A, Barlow J, et al. Design considerations in a clinical trial of a cognitive behavioural intervention for the management of low back pain in primary care: Back Skills Training Trial (BeST) Tean. BMC Musculoskelet Disord. 2007;8:14
5. Abreu AT, Ribeiro CA. Prevalência de lombalgia em trabalhadores submetidos ao programa de reabilitação profissional do Instituto Nacional do Seguro Social (INSS), São Luís, MA. Acta Fisiatr. 2010;17(4):148-52.

6. Pimenta CA. Dor crônica, terapia cognitiva comportamental e o enfermeiro. Rev Psiquiatr Clín. 2001;28(6):288-94.

7. Al-Obaidi SM, Beattie P, Al-Zoabi B, Al-Wekeel S. The relationship of anticipated pain and fear avoidance beliefs to outcome in patients with chronic low back pain who are not receiving workers compensation. Spine. 2005;30(9):1051-7.

8. Schultz IZ, Crook J, Meloche GR, Berkowitz J, Milner R, Zuberbier OA, et al. Psychosocial factors predictive of occupational low back disability: towards development of a return-to-work model. Pain. 2004;107(1-2):77-85.

9. Kerns RD, Sellinger J, Goodin BR. Psychological treatment of chronic pain. Annu Rev Clin Psychol. 2011;7:411-34.

10. Pimenta CA, da Cruz Dde A. [Chronic pain beliefs: validation of the survey of pain attitudes for the Portuguese Language]. Rev Esc Enferm USP. 2006;40(3):365-73. Portuguese.

11. Tait RC, Chibnall JT. Development of a brief version of the Survey of Pain Attitudes. Pain. 1997;70(2-3):229-35.

12. Oliveira JT. Aspectos comportamentais das síndromes de dor crônica. Arq Neuro-Psiquiatr. 2000;58:(Suppl2A):360-5.

13. Pagano T, Matsutani LA, Ferreira EA, Marques AP, Pereira CA. Assessment of anxiety and quality of life in fibromyalgia patients. São Paulo Med J. 2004;122(6):252-8.

14. Jensen MP, Karoly P, Huger R. The development and preliminary validation of an instrument to assess patient's attitudes toward pain. J Psychosom Res. 1987;31(3):393-400.

15. Castro MM, Quarantini L, Batista-Neves S, Kraychete DC, Dalto C, Miranda-Scippa A. [Validity of the hospital anxiety and depression scale in patients with chronic pain. Rev Bras Anestesiol. 2006;56(5):470-7. Portuguese.

16. Vigatto R, Alexandre NM, Correa Filho HR. Development of a Brazilian Portuguese version of the Oswestry Disability Index: cross-cultural adaptation, reliability and validity. Spine, 2007;32(4):481-6.

17. Fairbank JC, Pynsent PB. The Oswestry Disability Index. Spine. 2000;25(22):2940-52

18. Ferreira GD, Silva MC, Rombaldi AJ. Prevalência de dor nas costas e fatores associados em adultos do Sul do Brasil: estudo de base populacional. Rev Bras Fisioter. 2011;15(1):31-6.

19. Hoy D, Brooks P, Blyth F, Buchbinder R. The epidemiology of low back pain. Best Pract Res Clin Rheumatol. 2010;24(6):769-81.

20. Quiton RL, Greenspan JD. Sex differences in endogenous pain modulation by distracting and painful conditioning stimulation. Pain. 2007;132(Suppl 1):S134-49.

21. Henschke N, Maher CG, Refshauge KM, Herbert RD, Cumming RG, Bleasel J, et al. Prognosis in patients with recent onset low back pain in Australian primary care: inception cohort study. BMJ. 2008;337(a171):154-7.

22. Linton SJ, Gross D, Schultz IZ, Main C, Côté P, Pransky G, et al. Prognosis and the identification of workers risking disability: research issues and directions for future research. J Occup Rehabil. 2005;15(4):459-74.

23. Strine TW, Hootman JM, Chapman DP, Okoro CA, Balluz L. Health-related quality of life, health risk behaviors and disability among adults with pain-related activity difficulty. Am J Public Health. 2005;95(11):2042-8

24. Björck-van Dijken C, Fjellman-Wiklund A, Hildingsson C. Low back pain, lifestyle factors and physical activity: a population-based study. J Rehabil Med.2008;40(10):864-9.

25. Dawson AP, Steele EJ, Hodges PW, Stewart S. Utility of the Oswestry Disability Index for studies of back pain related disability in nurses: evaluation of psychometric and measurement properties. Int J Nurs Stud. 2010;47(5):604-7.

26. Peters Ml, Vlaeyen JW, Weber WE. The joint contribution of physical pathology, pain-related fear and catastrophizing to chronic back pain disability. Pain 2005;113(12):45-50.

27. Sardá J Jr, Nicholas MK, Asghari A, Pimenta CA. The contribution of self-efficacy and depression to disability and work status in chronic pain patients: a comparison between Australian and Brazilian samples. Eur J Pain. 2009;13(2):180-95.

28. Darlow B, Perry M, Stanley J, Mathieson F, Melhoh M, Baxter GD, et al. Cross-sectional survey of attitudes and beliefs about back pain in New Zealand. BMJ Open. 2014;4(5):e004725.

29. McCracken LM. Social context and acceptance of chronic pain: the role of solicitous and punishing responses. Pain. 2005;113(1-2):155-9.

30. Tait RC, Chibnall JT. Attitude profiles and clinical status in patients with chronic pain. Pain. 1998;78(1):49-57.

31. Turner JA, Jesen MP, Romano JM. Do beliefs, coping and catastrophizing indenpedently predict functioning in patients with chronic pain? Pain. 2000;85(1-2):115-25. 